\title{
The using of the SAVI Model to Improve Thematic Learning Outcomes in Elementary Students
}

\author{
Naeklan Simbolon ${ }^{1 *}$, Rospita Silaban ${ }^{2}$, Eva Betty Simanjuntak ${ }^{3}$ \\ ${ }^{1,2,3)}$ Faculty of Education, Universitas Negeri Medan-Indonesia \\ *naeklan@unimed.ac.id
}

\begin{abstract}
This study aims to improve student learning outcomes in thematic learning by applying the SAVI model for elementary students. There were two cycles in this research; each cycle divided into four stages: planning, implementation, observation, and reflection. Data gathered with multiple choice tests. Based on data analysis, in first cycle, $46.43 \%$ of the students had incompleted tests and $53.57 \%$ of the students had completed their tests. In the second cycle, $10 \%$ of the students had incompleted tests and $90 \%$ of the students had completed their tests. Thus, the use of the SAVI model can improve elementary school students' learning outcomes.
\end{abstract}

Keywords: SAVI Model, learning, thematic, elementary students

\section{Introduction}

The learning process is a step to develop cognitive, effective, and psychomotor abilities. The important role that the teacher has to go through this step is as a facilitator. The main goal of a good facilitator is to prepare a learning plan that cover the learning objectives and at the same time matches the characteristics of the students. The teachers have to have some skills and a broad knowledge about learning models and techniques and most importantly have the patient to put their efforts in applying those skills and knowledge into practice.

One of the learning approaches that specifically using themes to integrate different kind of competencies is called thematic learning. Through this learning strategy, teachers encourage the students to proactively engage in the learning process to get hands-on skills and knowledge. In addition to that, teachers also guide the students to exercise their analytical thinking and curiosity to find out something new to learn from the given tools and find the connection with other previous concepts that their learned. Two main problems encountered in thematic learning processes include: (1) the learning process is done conventionally which makes students feel bored when the learning process takes place, (2) the lack of facilities and infrastructure in the learning process. The SAVI (Somatic, Auditori, Visual, and Intellectual) learning model is used to overcome the problem. The following is a description of the variables studies.

\section{Understanding Learning}

According to Hamalik [1] learning is a modification or reinforce behavior through experience. Furthermore Wesly [2] said learning is a series of activities carried out by a person in interacting with the environment that results in changes in him, both knowledge, attitudes and skills. According to Ahmadi \& Amri [3] learning is a process of gaining knowledge and experience in the form of changes in behavior and the ability to react that is relatively settled because there is an interaction of individuals with their environment. 
According to Purwanto [4] learning outcomes are behavioral changes that occur after students follow learning in accordance with established goals. The learning process is a process that occurs in learners, and each individual displays a change in themselves. Suprijono [5] describes that learning outcomes are patterns of behaviors, meanings, thoughts, perspectives, affection, and experiences. Sudjana [6] says that learning outcomes are behavioral changes that cover the cognitive, affective, and psychomotor fields. Therefore, it can be concluded that learning is a process of changing individual behavior due to individual interactions with their environment.

The students achieved low learning outcomes because of some factors that affect their concentration during the learning process. For example, the class atmosphere that is not conducive makes students have some difficulties in listening to the teacher. Therefore, teachers need to direct and attract students' attention to the presented lessons. The teacher as a facilitator has to put some effort to create good learning conditions, develop learning materials properly, and improve students' ability to listen to the learning materials and achieve the learning objectives.

\section{Understanding of the SAVI Learning Model}

According to Lubis [7], a learning model is a methodical procedure in coordinating learning activities to accomplish educational objectives. The opinion above is also aligned with Cahyo [8] a learning model is interpreted as an orderly scheme in designing learning practices to attain learning purposes. Thus, a learning model is a meaningful and innovative design that is used in providing learning activities to students to achieve predetermined learning purposes.

The SAVI learning model highlights that learning needs to utilize students' senses completely. Rusman in Istarani [9] said that a complete system to involve the five senses and emotions in the learning process is a natural way of learning known as the SAVI model, namely Somatic, Auditory, Visual, and Intellectual. According to Huda [10] what teachers need to pay attention to implement the SAVI learning are: 1) Somatic, learning by playing or doing; 2) Auditory, learning by listening; 3) Visual, learning by seeing); 4) Intellectual, learning by understanding.

Somatic is learning through physical involvement, especially the sense of touch, during learning. In somatic learning, the body and mind are fused and by utilizing the body movement, students learn to experience and do the given tasks. Auditory learning utilizes talking and listening as a way to learn. Auditory thoughts are stronger than we realize. Auditory which means that learning must be through listening, speaking, presentation, argumentation, expressing opinions, and responding. Visual learning is learning by observing and describing. Meaningful visual learning must use the eye's senses through observation, drawing, demonstrating, reading, using media, and teaching aids. Intellectual learning is learning by solving problems that are by provoking student's mind inwardly to ponder on what is happening around him/her and formulate relationships, meanings, plans, and values from that experience.

\section{Stages of Implementation of the SAVI model}

According to Huda [10] the stages of the implementation of SAVI are as follows:

a. Somatic: Learning by Doing; 1) Design a project that can encourage students to move in different places; 2) demonstrate a process, system, or set of concepts; 3) ask students to write on a card about what they are learning; 4) ask them to display their ideas in the form of theater, expression or touch. 
b. Auditory: Learning by Hearing; 1) ask students to explain what they have learned from others; 2) ask students to read books or handouts aloud, if necessary with expressions that can show the character of a reading; 3 ) listen to the material presented and summarize it; 4) when reading the text, occasionally ask students to read the main ideas in the text aloud; 5) involve students in discussions and polls with other students.

c. Visual: Learning by Seeing; 1) Assign students to read one or two paragraphs, then ask them to make a brief synopsis of what they are reading. Continue to repeat this process; 2) ask students to continue to record every important explanation delivered in the classroom; 3) invite students to make a kind of mural, picture, or painting, then place it on the classroom wall; 4) spread the text of the subject matter, and make sure the text has been highlighted in different colors on important concepts; 5) draw a mindmap on the board, and ask students to pay close attention.

d. Intellectual: Learning by Thinking; 1 ) ask students to make a kind of diagram, or pictogram, that can illustrate what they reflect; 2) try asking probing questions about the subject matter that has been taught and ask students to think about the solution; 3) each time completing a learning experience, ask students to sit for a moment reflecting on what they have learned and relating it to what they already know.

\section{Understanding Integrative Thematic Learning}

Thematic is learning that uses themes and combines several subjects so that students can provide meaningful learning experiences into something real, simple, systematic, and clear. According to Kadir thematic learning is a learning program that departs from a particular theme/topic which is then elaborated from various aspects or reviewed from various perspectives of subjects that are normally recommended in schools [11].

According to Trianto [11] integrative thematic learning is a learning method that enables students, individually or in a group to actively investigate, examine, and learn scientific concepts and teachings authentically, meaningfully, and holistically. Integrated learning as a concept can be said as a learning strategy that links diverse subjects into one theme. Students perform an active part in exploration activities, learning material, and learning processes in several fields of study at the same time. According to Ahmadi and Amri [3] thematic learning is one attempt to combine creative knowledge, skills, attitudes, and thoughts by using them in learning. Based on those definitions, thematic learning is a learning activity by linking several fields of study in one theme, which emphasizes the involvement of students in learning.

\section{Research Method}

This research was conducted in July - September 2018 at SDN 106162 Medan Estate, involve 28 Grade VI students. The objective is to increase students' learning results in thematic learning using the SAVI learning model by using tests and observations to gather the required data. There were two parts conducted in this study, namely pre-test and post-test using multiple-choice questions. A pre-test is given before giving an action that aims to find out the extent of the students' initial ability in learning, while the test is given at the end of the meeting namely post-test cycle I and II aims to find out whether the student's ability to improve after being given action using the SAVI learning model. Researchers conduct data analysis of learning outcomes that aim to see the completeness of student learning outcomes. The analyzed data is taken from the students' answer sheets and the learning outcomes 
achievement level is obtained. The level of students' ability to solve problems is determined by the criteria for determining students' mastery level over the given material.

\section{Result and Discussion}

At the beginning of the study, the pre-test results showed students' average outcome was 58.57 , with 4 students achieve $14.28 \%$ and 24 students achieve $85.72 \%$, with mastery level in learning material was incomplete. Then the SAVI model applied in the learning process to improve students' learning outcomes. In the first cycle, the average value of students was 68.57 , and as many as 13 students achieve $46.43 \%$ with mastery level on the material was complete, and 15 students achieve $53.57 \%$ with mastery level on learning material was incomplete.

In the second cycle, researchers took action by paying attention to all the deficiencies that exist in the first cycle so that learning outcomes were even better. The students' average value was 77.68 and as many as 25 students accomplish $90 \%$ and the mastery level on the material was complete, and 3 students accomplish $10 \%$ with mastery level on the material was incomplete. In summary, the improvement in students' learning outcomes of class VI-A of SD Negeri 106162 Medan Estate shown in Table 1.

Table 1. Frequency of Learning Outcomes

\begin{tabular}{clccc}
\hline No & Data & Pre-test & Cycle I & Cycle II \\
\hline 1 & Average & 58,57 & 68,57 & 77,68 \\
2 & Complete & 4 & 13 & 25 \\
3 & Percentage & $14,28 \%$ & $46,43 \%$ & $90 \%$ \\
\hline
\end{tabular}

More clearly the improvement in student learning outcomes can be seen from the average pretest scores, the first cycle test result, and the second cycle test result depicted in Figure 1.

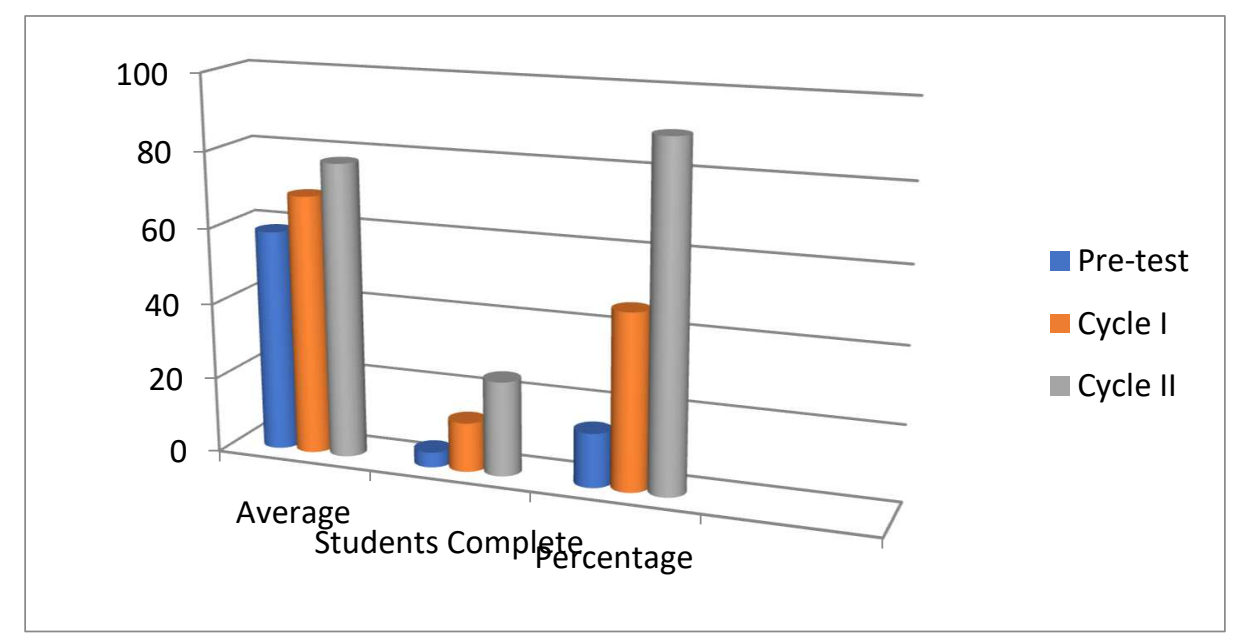

Figure 1. Diagram of Improving Learning Outcomes 
Based on cycle I data analysis, the use of SAVI models in learning improved students' learning outcomes. However, the improvement obtained was still not optimal. In cycle II, some actions were taken to pay attention to all the deficiencies that occurred in the first cycle to better the results. Thus, it can be concluded that the SAVI model can improve students' learning ability. This research is in line with research conducted by Nana Sutarna [12] which shows an increment in student learning outcomes after applying the SAVI learning model in social science subjects, social issues material in class IV SD Cimulya, Cimahi District, Kuningan.

Furthermore, research conducted by Djamaluddin Husita [13] apply the SAVI learning model, and in the first cycle, the research result showed that 17 people accomplish $71 \%$ of mastery level. By observing overall teacher activity, $71.2 \%$ of students with a good category and $59.3 \%$ of students with the average category. In the second cycle, 22 students out of 24 students or $89 \% . .92 \%$ of teacher activities are good categories, and $97 \%$ of student activities were very good categories. Research conducted by Nur Azizah et al.[14], showed that each cycle of action taken has increased in teacher performance, student activities, and student learning outcomes. The increase that occurred in cycle III has reached the desired target, so the cycle was stopped in cycle III.

Dadang Iskandar et al. [15] researched the SAVI model which results can be viewed from the improved percentage on learning mastery level from $52.2 \%$ in the first cycle to $78.3 \%$ in the second cycle, and $100 \%$ in the third cycle. The students' average grade grew from 44.3 in the pre-test with enough criteria, up to 91.3 with the criteria very well in cycle III. Moreover, the observations also showed that applying the model increased teachers' ability and students' engagement. The questionnaire feedback showed $100 \%$ of students excited about social science. Hence, it is advised that teachers employ the SAVI learning strategy to intensify students' analytical and critical thinking skills.

The success of this research further confirms by research conducted by Linda Septiyana [16]. The research described three findings. First, the SAVI learning model is better than the TSTS. Second, the writing skills of high critical thinking skills students are better than students who have low critical thinking skills. Third, there is an interaction between learning methods and the level of critical thinking on students' writing skills.

Research conducted by Hartati, Nugraheti Sismulyasih [17] shows that a good SAVI model has four steps. First, the preparatory stage where the teacher drives students to take a role in learning. Second, the delivery stage where the teacher directs students to carry out independent activities. Third, the training stage where at this stage the teacher directs students to choose a theme. Fourth, the final stage where the teacher gives feedback.

\section{Conclusion}

As a summary, this research applied the SAVI (Somatic, Auditory, Visual, and Intellectual) model in the thematic learning process. The pre-test results showed students' average value of 58.57 , followed by the first cycle improvement which obtained an average value of students at 68.57 , and an average value of students at 77.68 in the second cycle. Through the research, it was found that students' ability in learning increased optimally after two cycles of post-test. Thus, it is advised that teachers utilize the SAVI learning model in thematic learning. 


\section{Acknowledgement}

The author would like to thank all those who supported the implementation of this research. The author also thanks the Directorate of Education and Culture for providing funding for the implementation of this research. Hopefully the results of this study will be of benefit to us.

\section{References}

[1] Hamalik, Oemar. (2010). Proses Belajar Mengajar. Jakarta: Bumi Aksa.

[2] Wesly S, et al. (2015). Upaya Meningkatkan Hail Belajar Melalui Pembelajaran Kooperatif Model Jigsaw Pada Pembelajaran IPS Kelas IV SD Negeri 101776 Sampali. Jurnal Handayani, 3(2).

[3] Ahmadi dan Amri Sofan. (2013). Pengembangan \& Model Pembelajaran dalam Kurikulum. Jakarta: PT. Prestasi Pustaka.

[4] Purwanto. (2017). Evaluasi Hasil Belajar. Yogyakarta: Pustaka Belajar.

[5] Suprijono, Agus. (2010). Cooperative Learning. Yogyakarta: Pustaka Pelajar.

[6] Sudjana, Nana. (2016). Penilaian Hasil Proses Belajar Mengajar. Bandung: PT. Remaja Rosdakarya.

[7] Lubis, Effi Aswita. (2015). Strategi Belajar Mengajar. Medan: Perdana Publishing.

[8] Cahyo, Agus N. (2013). Panduan Aplikasi Teori-Teori Belajar Mengajar Teraktual dan Terpopuler. Yogyakarta: DIVA Press.

[9] Istarani. (2015). Model Pembelajaran Inovatif. Medan: Media Persada.

[10] Huda, Miftahul. (2014). Model-Model Pengajaran dan Pembelajaran. Yogyakarta: Pustaka Pelajar.

[11] Trianto. (2012). Mendesain Model Pembelajaran Inovatif-Progresif: Konsep, Landasan, dan Implementasinya pada Kurikulum Tingkat Satuan Pendidikan. Jakarta: Kencana.

[12] Sutarna, Nana. (2018). Pengaruh Model Pembelajaran SAVI (Somatic Auditory Visual Intellectualy) Terhadap Hasil Belajar Siswa Kelas IV Sekolah Dasar. Jurnal Profesi Pendidikan Dasar (JPPD), 5 (2), pp.119-126.

[13] Djamaluddin, Husita. (2014). Penerapan Metode Koperatif Tipe Savi (Somatic Auditory Visual and Intellectual) Animasi Komputasi Sederhana Untuk Meningkatkan Ketuntasan Belajar Kimia Pada Materi Ikatan Kimia Siswa Kelas X-6 Man. Lantanida Journal , 2(2), pp. $185-201$.

[14] Azizah Nur; Sujana Atep; Isrok'atun. (2016). Penerapan Pendekatan Somatis Auditori Visual Intelektual Pada Materi Sumber Energi Bunyi Untuk Meningkatkan Hasil Belajar Siswa Program Studi PGSD UPI. Jurnal Pena Ilmiah, 1(1), pp. 491 - 500.

[15] Dadang Iskandar, Acep Roni Hamdani, Teti Suhartini. (2016). Implementation Of Model SAVI (Somatic, Audiotory, Visualization, Intellectual) to Increase Critical Thinking Ability In Class IV of Social Science Learning on Social Issues in the Local Environment. Journal of Education, Teaching and Learning , 1(1), pp. 45-50. 
[16] Linda Septiyana. (2017). Somatic, Auditory, Visual, Intellectual (Savi): Its Effectiveness To Teach Writing From The Perspective Of Students' Critical Thinking. Journal of English Language Teaching. DOI: https://doi.org/10.32332/pedagogy.v4i2.382. Acccessed on 5 December 2019.

[17] Hartati, Nugraheti Sismulyasih. (2017). Development of SAVI (Somatic Auditory Visual and Intellectual) Learning Model with Audiovisual to Increase Writing Skill of Elementary Student. DOI: https://doi.org/10.2991/icset-17.2017.176. Acccessed on 5 December 2019. 